\title{
BIO-INOCULATION AND Zn APPLICATION AS AN ALTERNATIVE STRATEGY OF PARTIAL N-MINERAL NEEDS FOR ALLEVIATING THE POSSIBLE CHEMICAL POLLUTION OF SOME CEREAL CROPS
}

\author{
Mostafa A. Nasef, Ali M. Massoud and Medhat Y. Abou-Zeid
}

Soils, Water and Environment Res. Institute, Agric. Res. Center, Giza, Egypt

\section{ABSTRACT:}

This work is an important strategy for understanding the local best usage of either N-mineral or N-bio-sources, whether be under demand for agricultural utilization projects. Also, it represents a huge challenge and technical solution for alleviating the possible adverse fears of human health through environmental risks as a result of excessive use of the nitrogenous chemical fertilizers for fertilizing some cereal crops as well as to support the newly technique of "clean, bio- and organic agriculture".

So, a field experiment was conducted on a clayey soil during two successive seasons of 2008-2009 and 2009-2010 at Damas village, Mit Ghamer district, El-Dakahlia Governorate, Egypt, to identify the outcome of replacing $25 \%$ from the recommended N-mineral dose (RND) of wheat crop by using a bio-inoculation with Paenibacillus polymyxa bacteria under different rates of Zn-EDTA (i.e., 0, 1.0, 1.5 and $2.0 \mathrm{~kg} \mathrm{fed}^{-1}$ as soil application) on wheat (Triticum aestivum L., Sakha $93 \mathrm{cv}$.) vegetative growth as well as harvest crop parameters, i.e., spike characters, weight of 1000 grain, grain and straw yields/fed \& their nutrient contents of N, P, K, Fe, Mn, Zn and Cu. Soil content of available nitrogen forms $\left(\mathrm{NH}_{4}{ }^{+}\right.$and $\left.\mathrm{NO}_{3}{ }^{-}\right)$as related to nitrogenase enzyme in the soil after 70 days from sowing was taken into consideration in this study.

The obtained data show that grain bio-inoculation and Zn-chelate applied, as shown in the treatment (Paenibacillus polymyxa bacteria $+75 \%$ RND + highest $\mathrm{Zn}$ rate of $2 \mathrm{~kg} / \mathrm{fed}$ ), led to an almost similar plant vegetative parameters (i.e., plant height, No. of tillers plant ${ }^{-1}$, dry weight plant $^{-1}$, leaf chlorophyll a \& b and carotenoids) to those received the full recommended $\mathrm{N}$ mineral dose. However, the relative decrease percentages in such parameters were negotiable, insignificant and not exceeding $3 \%$. The reverse was true for available nitrogen forms $\left(\mathrm{NH}_{4}{ }^{+}\right.$and $\left.\mathrm{NO}_{3}{ }^{-}\right)$, mainly due to the pronounced increase in nitrogenase activity. The corresponding relative increase percentage in $\mathrm{N}$-forms recorded 18.77 and $8.51 \%$ over the soil treated with $100 \%$ RND, respectively. That was true, since such increases were more closely attributed to an achieved increase $(53.04 \%)$ in the nitrogenase activity of plant rhizosphere.

A similar way and a parallel trend for the growth parameters were observed with wheat spike characters (i.e., weight plant ${ }^{-1}$ and number plant ${ }^{-1}$ ), harvest crop parameters (i.e., grain weight plant $^{-1}$, straw weight plant ${ }^{-1}$, weight of 1000 grain, grain and straw yields fed ${ }^{-1}$ ), grain and straw contents of $\mathrm{N}, \mathrm{K}$, $\mathrm{Fe}, \mathrm{Mn}, \mathrm{Zn}$, and $\mathrm{Cu}$. However, the obtained values of these plant parameters were achieved negotiable and insignificant differences don't exceeding $2 \%$ at the treatment of (bio-inoculation $+75 \% \mathrm{RND}+$ highest $\mathrm{Zn}$-chelated rate of 2 $\mathrm{kg} / \mathrm{fed}$ ) as compared to those treated with full recommended $\mathrm{N}$-dose.

So, it could be said that the integrated combination between N-biofixation and applied soil $\mathrm{Zn}$-chelated leading to a continuous bio-fixed nitrogen slow release along the growth stages of wheat plants, to minimize its

Fayoum J. Agric. Res. \& Dev., Vol.24, No.2, July, 2010 
possible lose by either leaching process or volatilization, and in turn to rationalize use of $\mathrm{N}$-mineral fertilizers, which is surplus point for sustainable agriculture system. Such system represents a new agriculture strategy that affects the country's economy and its development. That is due to the possible adverse fears on either crop products or human health should be alleviated, besides it represents an ideal solution to meet the excessive nitrogenous fertilizers demand.

Key words: Wheat, grain bio-inoculation, Zn-application, nitrogenase activity.

\section{INTRODUCTION:}

Such studies may be helpful for identifying the best soil management to achieve the highest bio-agriculture production. Moreover, this situation demands to do serious rethinking in the agricultural research and extension with a view to evolve a "New Agricultural Strategy" to utilize the various diazotrophic bacteria as an alternative of a partial $\mathrm{N}$-mineral needs on a large scale for many cultivated crops, which can be environmentally safe. Such New Agricultural Strategy alleviates the hazardous effects on the grown plants not only in agriculture fields, but also human health through toxic elements persist in the ecosystem heaving accumulated in different tropic levels of the food chain as well as the dynamic equilibrium of the biosphere.

That is true, since World face a great problem either in the human health or in the environmental pollution. This problem is more related to many factors, the excessive use mineral or chemical fertilizers, especially those of nitrogenous ones, is one of them. Interest in the $\mathrm{N}$-excessive use, it could be partially attributed to the advent of high yielding crop cultivars, that need more N-requirements, under assured perennial irrigation. So, there is a renewed interest in either bio-fertilizer or organic recycling to improve soil fertility and its productivity. The periodical application of this natural technique has gained momentum in the recent past and called "organic agriculture, clean agriculture and bio-agriculture". The integrated use of the bio- and mineral fertilizers is considered the best option not only for reducing the previous enormous consumption of chemical fertilizers, but also maintain soil fertility status and help to sustain crop productivity (Singh et al., 1999; Bhatia et al., 2001 and Palm et al., 2001).

Germanous plants such as wheat are a major crop for food production. Since various diazotrophic bacteria have been found in association with germanous plants. They are possible candidates for beneficial interactions with agriculturally important crops. Paenibacillus polymyxa bacteria, which was formerly named Basillus polymyxa but has been classified by Ash et al. (1993), is commonly found in soil where it colonizes important crop species including wheat (Triticum aestivum L.), Mavingue et al. (1990). The naturally occurring soil bacteria that capable of simulating plants growth named as plant-growth-promotingrhizobacteria (PGPR) such as Bacillus spp. (Kloepper and Schorth 1981). Gouzou et al. (1993) demonstrated that inoculation of wheat with Paenibacillus polymyxa enhanced the rhizosphere effect by increasing the amount of adhering soil to improve soil structure. P. polymyxa is considered as $\mathrm{N}_{2}$-fixers; phosphate dissolving bacteria; phytohormones producers and antibiotic biosynthetic bacteria.

Fayoum J. Agric. Res. \& Dev., Vol.24, No.2, July, 2010 
BIO-INOCULATION AND Zn APPLICATION AS AN ALTERNATIVE...106

Ramadan et al. (2007) stated that $P$. polymyxa was active producers of indole acetic acid and gibberellins which produced as high as 167.0 and 584 $\mathrm{mg} / \mathrm{L}$. Another effect includes an increase in mobilization of insoluble nutrients followed by enhancement of uptake by the plants (Lifshutz et al., 1987). Moharram et al. (1997) reported that inoculation of wheat in a pot experiment with $B$. polymyxa together with organic and inorganic nitrogen application increased the dry weight ( $g_{\text {plant }}{ }^{-1}$ ) and $\mathrm{N}_{2}$-fixed $\left(\mathrm{mg} \mathrm{plant}^{-1}\right)$. Also, Abou-Zeid $\boldsymbol{e t}$ al. (2003) reported that bacterial inoculation, Azospirillum brasilense, Azotobacter chroococcum and Bacillus polymyxa led to significant increases in grain yield, grain protein and 1000 grain weight of wheat plants (Sakha $93 \mathrm{cv}$.).

Zinc is one of micronutrients required in trace amounts for plant growth. Since, it plays essential metabolic roles in plant and works as a regulatory cofactor for several enzymes. It is very closely involved in $\mathrm{N}$ metabolism of the plant. In zinc deficient plants protein synthesis and protein levels are markedly reduced, and amino acids and amides are accumulated. Also, Cakmak (2000) speculated that $\mathrm{Zn}$ deficiency stress may inhibit the activities of a number of antioxidant enzymes, chlorophyll and nucleic acids. Mahmoud (2001) observed that zinc fertilizers increased wheat growth and grain yield. This is mainly due to $\mathrm{Zn}$ plays a significant role in several physiological processes such as photosynthesis, respiration and either N-reduction or fixation.

Many of investigators are recognizing the importance of $\mathrm{Zn}$ for plant growth such as Moore and Patrick (1989) who reported that $\mathrm{Zn}$ plays an important role as a structural constituents or regulatory co-factor in a wide range of enzymes in many important biochemical pathways. There are mainly involved in: carbohydrate metabolism (photosynthesis and conversion of sugars to starch), protein metabolism (deficient plants often have reduced protein contents and elevated concentrations of certain free amino acids), auxin (growth regulator) metabolism (resulting stunning and/or resetting) and pollen formation (reduced production of pollen leads to a proportion of empty grains in the ears of selfpollinating cereals), Romheld and Marchner (1991). In addition, Ibrahim et al. (1991) observed that the highest values of plant height and dry matter of wheat plants, at tillering stage, were recorded when the application of aqua ammonia + Zn (either by soil or folialy).

So, it is of great interest to study the importance of $\mathrm{Zn}$ to plant and its relationship with either applied $\mathrm{N}$-mineral or N-bio-fixation. Therefore, the present work was aimed at identifying the effect of bio-inoculation and $\mathrm{Zn}$ application as an alternative strategy of a partial $\mathrm{N}$-mineral replacement on wheat vegetative growth, yield \& its components, nutrient contents of $\mathrm{N}, \mathrm{P}, \mathrm{K}, \mathrm{Fe}, \mathrm{Mn}, \mathrm{Zn}$ and $\mathrm{Cu}$ in both grain and straw. Soil content of available nitrogen forms $\left(\mathrm{NH}_{4}{ }^{+}\right.$and $\mathrm{NO}_{3}{ }^{-}$) as related to nitrogenase enzyme in the soil after 70 days from sowing was taken into consideration in this study.

\section{MATERIALS AND METHODS:}

\section{a. Materials:}

To achieve the aforementioned target, a field experiment was conducted on a clayey soil during two successive seasons of 2008-2009 and 2009-2010 at Damas village, Mit Ghamer district, El Dakahlia Governorate, Egypt. In this

Fayoum J. Agric. Res. \& Dev., Vol.24, No.2, July, 2010 
study, bio-inoculation with Paenibacillus polymyxa bacteria and micronutrient of $\mathrm{Zn}$-chelated as soil fertilization were applied. Some physical and chemical properties of the experimental soil were determined by using the standard methods as described by Black et al. (1965), Hesse (1971) and Jackson (1976), and the obtained data are present in Table (1).

Table (1): Some characteristics of the studied experimental soil at initial state.

\begin{tabular}{|c|c|c|c|}
\hline Soil character & Value & Soil character & Value \\
\hline \multicolumn{2}{|l|}{ Particle size distribution \%: } & $\mathrm{pH}(1: 2.5$,soil suspension) & 7.50 \\
\hline Sand & 15.70 & \multicolumn{2}{|c|}{ Chemical analysis of soil paste extract: } \\
\hline Silt & 39.30 & $\mathrm{ECe}\left(\mathrm{dS} \mathrm{m}{ }^{-1}\right)$ & 2.73 \\
\hline Clay & 45.00 & \multicolumn{2}{|l|}{ Soluble cations $\left(m\right.$ molc $\left.^{L-} 1\right)$ : } \\
\hline Textural class & Clay & \multicolumn{2}{|l|}{$\mathrm{Ca}^{++}$} \\
\hline $\mathrm{CaCO}_{3}$ content $\%$ & 2.80 & \multirow{4}{*}{$\begin{array}{l}\mathrm{Mg}^{++} \\
\mathrm{Na}^{+} \\
\mathrm{K}^{+} \\
\text {Soluble cations }\left(m \text { molc }^{L-} 1\right) \text { : }\end{array}$} & 3.71 \\
\hline Organic matter content $\%$ & 1.02 & & 7.03 \\
\hline CEC (c molc kg ${ }^{-1}$ soil) & 39.80 & & 0.55 \\
\hline Available $\mathrm{N} \quad\left(\mathrm{mg} \mathrm{kg}^{-1}\right)$ & 33.50 & & \\
\hline Available $\mathrm{P} \quad\left(\mathrm{mg} \mathrm{kg}^{-1}\right)$ & 9.64 & $\overline{\mathrm{CO}_{3}^{--}}$ & 0.00 \\
\hline Available $\mathrm{K} \quad\left(\mathrm{mg} \mathrm{kg}^{-1}\right)$ & 479.40 & $\mathrm{HCO}_{3}{ }^{-}$ & 3.43 \\
\hline Available $\mathrm{Zn}\left(\mathrm{mg} \mathrm{L}^{-1}\right)$ & 1.35 & $\mathrm{Cl}^{-}$ & 11.32 \\
\hline Available Mo $\left(\mathrm{mg} \mathrm{L}^{-1}\right)$ & 0.075 & $\mathrm{SO}_{4}^{--}$ & 12.74 \\
\hline
\end{tabular}

\section{b. Inoculants of bacteria used:}

Paenibacillus polymyxa bacterium was provided by Bio-fertilizer Production Unit, Department of Microbiology, Soils, Water and Environment Research Institute, Agric. Res. Center, Giza. The bacterium was own on maximum density $\left(10^{9}\right.$ cells $\left.\mathrm{mL}^{-1}\right)$ in Difico nutrient broth medium (Difico Manual, 1984) for $24 \mathrm{hrs}$. Grain inoculation was performed by dipping the grains in the bacterial culture; each grain received about $10^{6}$ cells $\mathrm{mL}^{-1}$ using Arabic Gum as adhesive agent. The grains were left for drying overnight before sowing.

\section{c. Field work:}

The experiment was designed in split-split design and comprised 36 treatments in three replicates. The main plots are represented by grain inoculated with Paenibacillus polymyxa bacteria and the sub-plots with Zn-EDTA, which contains $145 \mathrm{~g} \mathrm{Zn}$ per $\mathrm{kg}$ of $\mathrm{Zn}$-EDTA, at the rates of $0,1.0,1.5$ and $2.0 \mathrm{~kg} / \mathrm{fed}$ as soil application during land preparation for planting. The plot area is $10.5 \mathrm{~m}^{2}$ ( $3 \times 3.5 \mathrm{~m}$, i.e., $1 / 400 \mathrm{fed})$. Wheat grains (Triticum aestivum L. Sakha $93 \mathrm{cv}$.), which obtained from Field Crops Research Institute, Agric. Res. Center, Giza, were sown at $25^{\text {th }}$ of November in both agricultural growing winter seasons and harvested after 150 days. The phosphate and potassium fertilizers were added one month before sowing, where calcium superphosphate $\left(15 \% \mathrm{P}_{2} \mathrm{O}_{5}\right)$ and potassium $\left(48 \% \mathrm{~K}_{2} \mathrm{O}\right.$ ) fertilizers were added as single rates of 150 and $100 \mathrm{~kg} / \mathrm{fed}$, respectively. The nitrogen fertilizer was added at rates 100 and $75 \%$ of recommended dose $(80 \mathrm{~kg} \mathrm{~N} / \mathrm{fed})$ as urea form $(46.5 \mathrm{~N} \%)$ into two equal split portions, i.e., after 30 and 60 days from sowing. 


\section{d. Plant samples:}

Plants were randomly taken from each plot at 70 days after sowing to determine the vegetative growth parameters, i.e., i.e., plant height, No. of tillers plant $^{-1}$, dry weight plant ${ }^{-1}$, chlorophyll a $\&$ b and carotenoids. Rhizosphere zone adjacent to wheat roots was collected at 70 days from sowing to assay the activity of nitrogenase enzyme $\left(\mathrm{N}_{2}\right.$-ase $)$ as $\mathrm{n}$ mole $\mathrm{C}_{2} \mathrm{H}_{4} \mathrm{~g}^{-1}$ dry plant ${ }^{-1} \mathrm{~h}^{-1}$ by using the acetylene reduction technique (Hardy et al., 1973). As for leaf pigments, plant samples from the fourth upper leaves were obtained at 70 days after sowing, both chlorophyll a \& b and carotenoids were determined colorimetrically according to the methods described by Wettstein (1957).

At harvest, wheat spike characters (i.e., weight plant $^{-1}$ and number plant ${ }^{-1}$ ), harvest parameters (i.e., grain weight plant ${ }^{-1}$, straw weight plant $^{-1}$, weight of 1000 grain, grain and straw yields fed ${ }^{-1}$ ), grain and straw contents of $\mathrm{N}, \mathrm{K}, \mathrm{Fe}, \mathrm{Mn}, \mathrm{Zn}$, and $\mathrm{Cu}$ were determined. The grains were dried, ground and digested according to Peterburgski (1968). Nitrogen was determined using microkjeldahl, phosphorus by stannous chloride method as described by A.O.A.C (1980) and $\mathrm{K}$ was determined by using Flame Photometer (Yamagnchi and Minges 1956). $\mathrm{Fe}, \mathrm{Mn}, \mathrm{Zn}$, and $\mathrm{Cu}$ were determined using Atomic Absorption Spectrophotometer Perkin Elmer 3110, according to Cottenie et al. (1982).

\section{e. Soil samples:}

Soil samples were collected at 70 days after sowing to determine the soil available nitrogen forms of $\mathrm{NH}_{4}{ }^{+}$and $\mathrm{NO}_{3}{ }^{-}$by using Technician Auto Analyzer according to Markus et al. (1982).

\section{f. Statistical analysis:}

All data obtained of both the two studied seasons were averaged in a mean value for each of the tested plant and soil parameters, and then statistically analyzed by using L.S.D. at 0.05 as described by Snedecor and Cochran (1980).

\section{RESULTS AND DISCUSSION:}

\section{A general view on the characteristics of the experimental soil:}

The field work and analytical data (Table, 1) of the representative soil ample leads to a good knowledge about the main characteristics of the experimental site, which is mainly encompassing the Nile alluvium as a parent material, developed on recent alluvial Nile Delta of Egypt. The climatic conditions characterized by a long hot rainless summer and short mild winter, with scare amounts of rainfall. The ground water table not appeared till $150 \mathrm{~cm}$ depth from ground surface due to the presence of an efficient field ditches, which were limited the current soil depth. Also, it is characterized by clay in texture, non-saline, non-sodic, non-calcareous in nature, well drained and sub-angular blocky in structure. These conditions are stood in harmony with the fact that the studied soil is predominated by the clay fraction $(45.0 \%)$, which is more capable to retain adequate water and nutrients for growing plants.

II. Vegetative growth parameters of wheat as affected by the applied treatments:

Data in Table (2) reveal that the vegetative growth parameters (i.e., plant height, No. of tillers/plant, dry weight/plant, chlorophyll a \& b and carotenoids) of

Fayoum J. Agric. Res. \& Dev., Vol.24, No.2, July, 2010 
wheat plants after 70 days from sowing at the applied treatment of (graininoculation with Paenibacillus polymaxa bacteria $+75 \%$ recommended nitrogen dose (RND) + highest Zn-chelated rate of $2.0 \mathrm{~kg} / \mathrm{fed}$ ) were achieved almost similar values for those obtained from the treatment of $100 \%$ RND. That was true, since the treatment of (bio-inoculation $+\mathrm{Zn}$ ) exhibits a fewer decrease in each of the studied vegetative growth parameters, and such negotiable decreases can't be reach any degree of signification. That is also confirmed by the corresponding relative decrease percentages which were not exceeding $3 \%$, i.e., $1.49,2.71,1.76,1.60,2.59$ and $2.95 \%$, respectively.

In this respect, Mohsen et al. (2004) and Bakry et al. (2005) reported that applying the bacterial fertilizer to the experimental soil influenced the most test characters in the direction of improving growth, photosynthesis and dry matter accumulation of the plant. Also, the increase in plant synthetic pigments as a result of bacterial inoculation may be attributed to increases in fixed nitrogen in plants via an increase of $\mathrm{N}_{2}$-ase enzyme activity of bacteria as shown in Table (3), where nitrogen is a major component of chlorophyll. These findings are in line with those obtained by Massoud et al. (2008). In this respect, El-Kabbany (1992) indicated that the applied $\mathrm{Zn}$ also increased chlorophyll content of wheat leaves.

Table (2): Effect of grain inoculation and different applied Zn-rates as soil application on wheat vegetative growth parameters after 70 days of planting.

\begin{tabular}{|c|c|c|c|c|c|c|c|}
\hline \multicolumn{2}{|c|}{ Treatment } & \multirow{2}{*}{$\begin{array}{l}\text { Plant } \\
\text { height } \\
(\mathrm{cm})\end{array}$} & \multirow{2}{*}{$\begin{array}{c}\text { No. of } \\
\text { tillers/ } \\
\text { plant }\end{array}$} & \multirow{2}{*}{$\begin{array}{c}\text { Dry } \\
\text { weight/ } \\
\text { plant }\end{array}$} & \multirow{2}{*}{$\begin{array}{c}\text { Chlorophyll } \\
\text { a } \\
\text { (mg/g DW) }\end{array}$} & \multirow{2}{*}{$\begin{array}{c}\text { Chlorophyll } \\
\text { b } \\
(\mathrm{mg} / \mathrm{g} \mathrm{DW})\end{array}$} & \multirow[b]{2}{*}{$\begin{array}{c}\text { Carotenoids } \\
(\mathrm{mg} / \mathrm{g} \mathrm{DW})\end{array}$} \\
\hline $\begin{array}{l}\text { N-source } \\
\text { (A) }\end{array}$ & $\begin{array}{c}\mathrm{Zn} \text { rate } \\
(\mathrm{B}, \mathrm{kg} / \mathrm{fed})\end{array}$ & & & & & & \\
\hline \multirow{4}{*}{$\begin{array}{l}100 \% \text { RND } \\
\text { as a control }\end{array}$} & 0 & 98.17 & 3.65 & 5.47 & 5.91 & 2.94 & 2.74 \\
\hline & 1.0 & 102.24 & 4.11 & 7.61 & 6.57 & 3.70 & 3.35 \\
\hline & 1.5 & 106.50 & 4.88 & 8.24 & 6.79 & 3.96 & 3.80 \\
\hline & 2.0 & $109.86^{*}$ & $5.54 *$ & $9.05^{*}$ & $6.86^{*}$ & $4.25^{*}$ & $4.07 *$ \\
\hline \multicolumn{2}{|c|}{ Mean } & 104.19 & 4.54 & 7.59 & 6.53 & 3.71 & 3.50 \\
\hline \multirow{4}{*}{$\begin{array}{l}75 \% \text { RND } \\
\text { without bio- } \\
\text { inoculation }\end{array}$} & 0 & 79.65 & 2.86 & 4.27 & 4.32 & 2.15 & 2.10 \\
\hline & 1.0 & 90.21 & 3.52 & 6.52 & 6.09 & 3.42 & 2.89 \\
\hline & 1.5 & 94.72 & 4.18 & 7.15 & 6.25 & 3.56 & 3.36 \\
\hline & 2.0 & 97.89 & 4.75 & 8.07 & 6.30 & 3.91 & 3.58 \\
\hline \multicolumn{2}{|c|}{ Mean } & 90.62 & 3.83 & 6.63 & 5.74 & 3.26 & 2.98 \\
\hline \multirow{4}{*}{$\begin{array}{l}75 \% \text { RND } \\
\text { with bio- } \\
\text { inoculation }\end{array}$} & 0 & 96.98 & 3.41 & 5.20 & 5.73 & 2.81 & 2.62 \\
\hline & 1.0 & 101.73 & 3.97 & 7.38 & 6.40 & 3.56 & 3.25 \\
\hline & 1.5 & 105.30 & 4.65 & 7.95 & 6.64 & 3.80 & 3.67 \\
\hline & 2.0 & $108.25 *$ & $5.39 *$ & $8.89 *$ & $6.75^{*}$ & $4.14 *$ & $3.95 *$ \\
\hline \multicolumn{2}{|c|}{ Mean } & 103.07 & 4.36 & 7.35 & 6.38 & 3.56 & 3.37 \\
\hline \multirow{3}{*}{$\begin{array}{l}\text { L.S.D. at } \\
\quad 0.05\end{array}$} & A & 2.550 & 0.390 & 0.410 & 0.340 & 0.210 & 0.084 \\
\hline & B & 1.320 & 0.160 & 0.170 & 0.120 & 0.150 & 0.075 \\
\hline & $\mathrm{A} \times \mathrm{B}$ & n.s. & n.s. & 0.250 & n.s. & n.s. & 0.106 \\
\hline \multicolumn{2}{|c|}{$*$ Relative decrease $\%$} & 1.49 & 2.71 & 1.76 & 1.60 & 2.59 & 2.95 \\
\hline
\end{tabular}

$*$ Relative decrease $\%=$ the difference between both treatments $\%$

Data also showed that application of Zn-chelated was not only enhance the activities of antioxidant enzymes, chlorophyll and nucleic acids (Cakmak, 2000), but also it plays a significant role in several physiological processes of photosynthesis, respiration and either N-reduction or N-bio-fixation (Mahmoud, 2001). In addition, Ibrahim et al. (1991) observed that the highest values of plant height and dry matter of wheat plants, at tillering stage, were recorded when the

Fayoum J. Agric. Res. \& Dev., Vol.24, No.2, July, 2010 
BIO-INOCULATION AND Zn APPLICATION AS AN ALTERNATIVE... 110

application of aqua ammonia $+\mathrm{Zn}$, added either by soil or foliarly. Moreover, the effect of Zn-chelated, Table (2), was more pronounced with increasing the applied rates, where the highest $\mathrm{Zn}$-chelated dose $(2 \mathrm{~kg} / \mathrm{fed})$ led to significant increases in all the studied parameters. In this concern, Vallee and Falchuk (1993) emphasized the favorable effect of $\mathrm{Zn}$-chelated on plant growth to its role through DNA and RNA metabolism in cell division and protein synthesis that is essential.

Table (3): Effect of grain inoculation and different applied Zn-rates as soil application on $\mathrm{N}$-forms and nitrogenase activity after 70 days of planting.

\begin{tabular}{|c|c|c|c|c|}
\hline \multicolumn{2}{|c|}{ Treatment } & \multirow{2}{*}{$\begin{array}{c}\text { Nitrogenase } \\
\text { activity (n mole } \\
\mathrm{C}_{2} \mathrm{H}_{4} / \text { plant/h) }\end{array}$} & \multicolumn{2}{|c|}{ Available N-forms (mg/kg soil } \\
\hline $\begin{array}{l}\mathrm{N} \text {-source } \\
\text { (A) }\end{array}$ & $\begin{array}{c}\text { Zn rate } \\
(\mathrm{B}, \mathrm{kg} / \mathrm{fed})\end{array}$ & & $\mathrm{N}-\mathrm{NH}_{4}{ }^{+}$ & $\mathrm{N}-\mathrm{NO}_{3}^{-}$ \\
\hline \multirow{4}{*}{$\begin{array}{l}100 \% \text { RND } \\
\text { as a control }\end{array}$} & 0 & 21.84 & 10.45 & 25.10 \\
\hline & 1.0 & 27.59 & 12.60 & 29.83 \\
\hline & 1.5 & 34.72 & 14.74 & 33.56 \\
\hline & 2.0 & $39.36^{*}$ & $18.52 *$ & $37.95 *$ \\
\hline \multicolumn{2}{|c|}{ Mean } & 30.87 & 14.08 & 31.61 \\
\hline \multirow{4}{*}{$\begin{array}{l}75 \% \text { RND } \\
\text { without bio- } \\
\text { inoculation }\end{array}$} & 0 & 23.15 & 7.88 & 18.73 \\
\hline & 1.0 & 28.85 & 9.30 & 22.04 \\
\hline & 1.5 & 35.30 & 10.95 & 24.80 \\
\hline & 2.0 & 41.06 & 13.60 & 27.95 \\
\hline \multicolumn{2}{|c|}{ Mean } & 32.09 & 10.43 & 23.38 \\
\hline \multirow{4}{*}{$\begin{array}{l}75 \% \text { RND } \\
\text { with bio- } \\
\text { inoculation }\end{array}$} & 0 & 46.37 & 12.92 & 29.80 \\
\hline & 1.0 & 58.65 & 15.74 & 31.26 \\
\hline & 1.5 & 71.74 & 17.15 & 36.30 \\
\hline & 2.0 & $83.82 *$ & $22.80^{*}$ & $41.48 *$ \\
\hline \multicolumn{2}{|c|}{ Mean } & 65.14 & 17.15 & 34.70 \\
\hline \multirow{3}{*}{$\begin{array}{l}\text { L.S.D. at } \\
0.05\end{array}$} & $\mathrm{~A}$ & 4.27 & 0.41 & 0.38 \\
\hline & $\mathrm{B}$ & 5.68 & 0.39 & 0.27 \\
\hline & $\mathrm{A} \times \mathrm{B}$ & 7.53 & 0.57 & 0.41 \\
\hline \multicolumn{2}{|c|}{$*$ Relative increase \% } & 53.04 & 18.77 & 8.51 \\
\hline
\end{tabular}

$*$ Relative increase $\%=$ the difference between both treatments $\%$

\section{Soil available $\mathrm{N}$-forms as related to $\mathrm{N}_{2}$-ase activity:}

Biological $\mathrm{N}_{2}$-fixation by Paenibacillus polymaxa symbioses is vitally important as $\mathrm{N}$ input in agro-ecosystem. Table (3) shows that grain inoculation with such inoculants of bacteria significantly increased the available contents of $\mathrm{N}$-forms due to nitrogenase activity after 70 days of sowing. This is emphasized by the relative increase percentages in $\mathrm{N}$-forms that are reached 18.77 and 8.51 for $\mathrm{N}_{-} \mathrm{NH}_{4}{ }^{+}$and $\mathrm{N}-\mathrm{NO}_{3}{ }^{-}$, respectively. These results are in line with those reported by Abdel-Ghaffar et al. (1994) and Massoud $\boldsymbol{e t}$ al. (2008). Data in Tables (2 and 3 ) show also that either the vegetative growth parameters or available $\mathrm{N}$ content after 70 days of sowing exhibited gradual significantly increases with increasing the applied Zn-chelated rates. Such mentioned investigated scope tended to gradual and parallel increases in nitrogenase activity values with increment of $\mathrm{Zn}$ chelated rates up to the highest one $(2 \mathrm{~kg} / \mathrm{fed})$, at that rate $\mathrm{N}_{2}$-ase recorded the greatest value of $83.82 \mathrm{n}$ mole $\mathrm{C}_{2} \mathrm{H}_{4} / \mathrm{plant} / \mathrm{h}$. These results are in agreement with those obtained by Vessey (2004).

Fayoum J. Agric. Res. \& Dev., Vol.24, No.2, July, 2010 
The positive effect of $\mathrm{Zn}$ on $\mathrm{N}_{2}$-ase activity may be due to its role which acts as metal component for some enzymes or as a functional structural or regulatory cofactor for the others, hence it could be attributed the positive effect of $\mathrm{Zn}$ on $\mathrm{N}_{2}$-ase activity to the improved nutritional status of nitrogen fixing bacteria by indirect way (Abadi $\boldsymbol{e t}$ al., 1995). Also, that favourable condition was more obvious in case of the interaction effect of bio-inoculation and soil application with $\mathrm{Zn}$-chelated. These obtained results are also in harmony with those obtained by Reda et al. (2006) and Moursy et al. (2008) who found that inoculation with some $\mathrm{N}_{2}$-fixing bacteria led to increase the activity of $\mathrm{N}_{2}$-ase enzyme in both rhizosphere and phyllosphere of wheat plants as compared with uninoculated plants, particularly at elongation stage of 80 days from sowing.

\section{$I V$. Wheat yield and its components:}

Data presented in Table (4) show that both grain inoculation with Paenibacillus polymaxa bacteria and applied $\mathrm{Zn}$-chelated rates greatly supported the obtained values of spike characters (i.e., weight plant ${ }^{-1}$ and number plant ${ }^{-1}$ ) and harvest parameters (i.e., grain weight plant ${ }^{-1}$, straw weight plant $^{-1}$, weight of 1000 grain, grain and straw yields fed ${ }^{-1}$ ) after 150 days from sowing.

Table (4): Effect of grain inoculation and different applied Zn-rates as soil application on wheat harvest parameters after 150 days of planting.

\begin{tabular}{|c|c|c|c|c|c|c|c|c|}
\hline \multicolumn{2}{|c|}{ Treatment } & \multirow{2}{*}{$\begin{array}{l}\text { Spikes } \\
\text { weight/ } \\
\text { plant g) }\end{array}$} & \multirow{2}{*}{$\begin{array}{l}\text { No. of } \\
\text { spikes/ } \\
\text { plant }\end{array}$} & \multirow{2}{*}{$\begin{array}{c}\text { Grain } \\
\text { weight/ } \\
\text { plant }\end{array}$} & \multirow{2}{*}{$\begin{array}{c}\text { Straw } \\
\text { weight/ } \\
\text { plant }\end{array}$} & \multirow{2}{*}{$\begin{array}{l}\text { Weight } \\
\text { of } 1000 \\
\text { grain }\end{array}$} & \multirow{2}{*}{$\begin{array}{c}\text { Grain } \\
\text { yield } \\
\text { (ardab/fed) }\end{array}$} & \multirow{2}{*}{$\begin{array}{c}\text { Straw } \\
\text { yield } \\
\text { (ton/fed) }\end{array}$} \\
\hline $\begin{array}{l}\text { N-source } \\
\text { (A) }\end{array}$ & $\begin{array}{c}\text { Zn rate } \\
(\mathrm{B}, \mathrm{kg} / \mathrm{fed})\end{array}$ & & & & & & & \\
\hline \multirow{4}{*}{$\begin{array}{l}100 \% \text { RND } \\
\text { as a control }\end{array}$} & 0 & 1.64 & 3.31 & 6.97 & 10.16 & 46.40 & 16.75 & 3.78 \\
\hline & 1.0 & 2.03 & 3.58 & 7.65 & 12.10 & 48.36 & 17.63 & 4.21 \\
\hline & 1.5 & 2.51 & 3.94 & 8.07 & 13.75 & 51.25 & 19.81 & 4.65 \\
\hline & 2.0 & $2.80 *$ & $4.27 *$ & $8.59 *$ & $14.80^{*}$ & $53.02 *$ & $22.15 *$ & $4.93 *$ \\
\hline \multicolumn{2}{|c|}{ Mean } & 2.24 & 3.78 & 7.82 & 12.71 & 49.76 & 19.08 & 4.40 \\
\hline \multirow{4}{*}{$\begin{array}{l}75 \% \text { RND } \\
\text { without bio- } \\
\text { inoculation }\end{array}$} & 0 & 1.41 & 2.75 & 6.13 & 9.02 & 40.61 & 14.47 & 3.25 \\
\hline & 1.0 & 1.76 & 3.10 & 6.78 & 10.63 & 42.34 & 15.83 & 3.60 \\
\hline & 1.5 & 2.15 & 3.46 & 7.10 & 12.08 & 45.05 & 17.62 & 4.00 \\
\hline & 2.0 & 2.39 & 3.69 & 7.45 & 12.99 & 47.19 & 19.70 & 4.30 \\
\hline \multicolumn{2}{|c|}{ Mean } & 1.93 & 3.25 & 6.86 & 11.18 & 43.80 & 16.90 & 3.79 \\
\hline \multirow{4}{*}{$\begin{array}{l}75 \% \text { RND } \\
\text { with bio- } \\
\text { inoculation }\end{array}$} & 0 & 1.59 & 3.23 & 6.78 & 9.95 & 45.30 & 16.30 & 3.65 \\
\hline & 1.0 & 1.98 & 3.50 & 7.51 & 11.87 & 47.57 & 17.39 & 4.10 \\
\hline & 1.5 & 2.45 & 3.86 & 7.89 & 13.50 & 50.14 & 19.50 & 4.52 \\
\hline & 2.0 & $2.76^{*}$ & $4.19 *$ & $8.48 *$ & $14.51 *$ & $51.98^{*}$ & $21.97 *$ & $4.84 *$ \\
\hline \multicolumn{2}{|c|}{ Mean } & 2.19 & 3.69 & 7.67 & 12.45 & 48.75 & 18.79 & 4.28 \\
\hline \multirow{3}{*}{$\begin{array}{l}\text { L.S.D. at } \\
\quad 0.05\end{array}$} & $\mathrm{~A}$ & 0.08 & 0.17 & 0.60 & 0.59 & 1.74 & 0.73 & 0.17 \\
\hline & $\mathrm{B}$ & 0.17 & 0.10 & 0.25 & 0.34 & 1.09 & 0.41 & 0.23 \\
\hline & $\mathrm{A} \times \mathrm{B}$ & n.s. & n.s. & 0.35 & n.s. & n.s. & n.s. & n.s. \\
\hline \multicolumn{2}{|c|}{$*$ Relative decrease \% } & 1.43 & 1.87 & 1.28 & 1.95 & 1.96 & 0.81 & 1.82 \\
\hline
\end{tabular}

*Relative decrease $\%=$ the difference between both treatments $\%$

$$
\text { Ardab }=150 \mathrm{~kg} \text { grain }
$$

In details, negotiable and insignificant differences don't exceeding $2 \%$ at the treatment of (bio-inoculation with Paenibacillus polymyxa $+75 \%$ RND in combination with the applied highest $\mathrm{Zn}$-chelated rate of $2 \mathrm{~kg} / \mathrm{fed}$ ) as compared to those treated with full recommended $\mathrm{N}$-dose. That was true, since the corresponding relative decrease percentages were not exceeding $2 \%$, i.e., 1.43, 1.87, 1.28, 1.95, 1.96, 0.81 and $1.82 \%$, respectively. These results are in line with those obtained by Aly (2003) who stated that some bacteria such as Azotobacter chroococcum

Fayoum J. Agric. Res. \& Dev., Vol.24, No.2, July, 2010 


\section{BIO-INOCULATION AND Zn APPLICATION AS AN ALTERNATIVE... 112}

and Paenibacillus polymyxa are capable to produce some hormones which induces the proliferation roots and root hair that increase nutrient absorbing surfaces as well as produce organic acids, which solublize inorganic and organic forms of mineral elements, and consequently increase stems, leaves and spikes then the straw and grain yield.

The obtained results are in harmony with those obtained by Kotb (1998) who showed that wheat spikes number $/ \mathrm{m}^{2}$, grains number spikes ${ }^{-1}$, spike grains weight, grain and straw yields fed $^{-1}$ were significantly increased either with increasing nitrogen fertilization up to $75 \mathrm{~kg} \mathrm{fed}^{-1}$ or with inoculation by $P$. polymyxa and Azospirillum lipoferum. Also, Abou-Zeid et al. (2003) reported that bacterial inoculation with Azospirillum brasilense, Azotobacter chroococcum and Bacillus polymyxa led to significant increases in grain yield, grain protein and 1000 grain weight of wheat plants (Sakha $93 \mathrm{cv}$.).

\section{Macro and micronutrients status in wheat grains and straw:}

Grain and straw nutrient contents of $\mathrm{N}, \mathrm{P}, \mathrm{K}, \mathrm{Fe}, \mathrm{Mn}, \mathrm{Zn}$ and $\mathrm{Cu}$ are presented in Tables (5 and 6).

Table (5): Effect of grain inoculation and different applied Zn-rates as soil application on content of macro- and macro-nutrients uptake of wheat grains.

\begin{tabular}{|c|c|c|c|c|c|c|c|c|}
\hline \multicolumn{2}{|c|}{ Treatment } & \multicolumn{3}{|c|}{ Macronutrients (kg/fed) } & \multicolumn{4}{|c|}{ Micronutrients (mg/kg dry material) } \\
\hline $\mathrm{N}$-source (A) & $\begin{array}{c}\mathrm{Zn} \text { rate } \\
(\mathrm{B}, \mathrm{kg} / \mathrm{fed})\end{array}$ & $\mathrm{N}$ & $\mathrm{P}$ & $\mathrm{N}$ & $\mathrm{Fe}$ & Mn & $\mathrm{Zn}$ & $\mathrm{Cu}$ \\
\hline \multirow{4}{*}{$\begin{array}{l}100 \% \text { RND } \\
\text { as a control }\end{array}$} & 0 & 41.25 & 7.94 & 22.17 & 75.32 & 28.35 & 20.10 & 11.00 \\
\hline & 1.0 & 45.05 & 9.37 & 26.85 & 80.45 & 32.20 & 42.82 & 12.07 \\
\hline & 1.5 & 48.68 & 10.46 & 31.44 & 89.61 & 37.64 & 54.75 & 15.18 \\
\hline & 2.0 & $58.15 *$ & $12.25 *$ & $37.60 *$ & $97.40 *$ & $41.80 *$ & $61.53 *$ & $19.09 *$ \\
\hline \multicolumn{2}{|c|}{ Mean } & 48.42 & 10.01 & 29.51 & 85.69 & 34.49 & 44.80 & 14.33 \\
\hline \multirow{4}{*}{$\begin{array}{l}75 \% \text { RND } \\
\text { without bio- } \\
\text { inoculation }\end{array}$} & 0 & 34.75 & 6.97 & 19.79 & 64.55 & 24.85 & 17.84 & 9.76 \\
\hline & 1.0 & 38.14 & 8.65 & 23.58 & 69.70 & 28.60 & 36.99 & 10.81 \\
\hline & 1.5 & 41.50 & 9.48 & 27.20 & 77.83 & 32.74 & 47.76 & 13.65 \\
\hline & 2.0 & 46.69 & 10.75 & 32.80 & 84.90 & 36.90 & 53.69 & 16.89 \\
\hline \multicolumn{2}{|c|}{ Mean } & 40.27 & 8.96 & 25.84 & 74.24 & 30.77 & 39.07 & 12.78 \\
\hline \multirow{4}{*}{$\begin{array}{l}75 \% \text { RND } \\
\text { with bio- } \\
\text { inoculation }\end{array}$} & 0 & 39.97 & 7.70 & 21.80 & 72.89 & 26.87 & 20.30 & 10.78 \\
\hline & 1.0 & 44.45 & 9.15 & 26.15 & 78.62 & 30.98 & 42.18 & 11.90 \\
\hline & 1.5 & 47.50 & 10.30 & 30.70 & 86.50 & 36.06 & 53.97 & 14.75 \\
\hline & 2.0 & $57.94 *$ & $11.97 *$ & $36.96^{*}$ & $95.81 *$ & $40.65 *$ & $60.45^{*}$ & 18.97* \\
\hline \multicolumn{2}{|c|}{ Mean } & 47.45 & 9.78 & 28.90 & 83.45 & 33.64 & 44.22 & 14.10 \\
\hline \multirow{3}{*}{$\begin{array}{l}\text { L.S.D. at } \\
\quad 0.05\end{array}$} & A & 2.69 & 0.36 & 1.56 & 2.59 & 3.23 & 1.64 & 0.79 \\
\hline & $\mathrm{B}$ & 2.66 & 0.61 & 1.84 & 1.68 & 4.47 & 2.79 & 1.35 \\
\hline & $\mathrm{A} \times \mathrm{B}$ & 3.76 & n.s. & n.s. & 2.36 & n.s. & n.s. & 2.40 \\
\hline \multicolumn{2}{|c|}{ *Relative decrease \% } & 0.36 & 2.28 & 1.86 & 1.63 & 2.75 & 1.75 & 0.63 \\
\hline
\end{tabular}

$*$ Relative decrease $\%=$ the difference between both treatments $\%$

The obtained data showed that wheat grain inoculation $+75 \%$ RND plus applied $\mathrm{Zn}$-chelated resulted in a significantly increase, especially at the highest rate of $\mathrm{Zn}$, for each of all tested nutrients as compared to the uninoculated one, but their obtained values still become usefulness as compared to those treated with $100 \%$ RND. The corresponding relative decrease percentages were $0.36,2.28$, $1.86,1.63,2.75,1.75$ and $0.63 \%$ for grains vs $0.48,1.86,1.85,1.79,1.23,1.36$ and 1.13 , respectively. Such differences represent fewer decreases and don't reach

Fayoum J. Agric. Res. \& Dev., Vol.24, No.2, July, 2010 
any degree of signification, where their relative decrease percentages are ranged between $0.36-2.75$ and $0.48-1.86 \%$ for wheat grain and straw, respectively.

The response of nutrients contents in wheat grain and straw to bioinoculation with Paenibacillus polymyxa bacteria and soil application of with $\mathrm{Zn}$ chelated rates showed significantly increased for all studied nutrients uptake by wheat grain and straw. This may be due to increased root growth and utilization of $\mathrm{N}$ released from bio-fixation along the different growth stages enable the grown plants to absorb more nutrients. These findings are in agreement with those reported by Kloepper (2003) who pointed out that phytohormones producer bacteria causes pronounced increases for wheat root elongation by then uptake of more nutrients via the root system, and hence utilization of $\mathrm{N}$ as a result of bioinoculation plays a dual role by fixation of atmospheric $\mathrm{N}$ and producing antimicrobial agents against deleterious rhizosphere bacteria.

Table (6): Effect of grain inoculation and different applied $\mathrm{Zn}$-rates as soil application on content of macro- and macro-nutrients uptake of wheat straw.

\begin{tabular}{|c|c|c|c|c|c|c|c|c|}
\hline \multicolumn{2}{|c|}{ Treatment } & \multicolumn{3}{|c|}{ Macronutrients (kg/fed) } & \multicolumn{4}{|c|}{ Micronutrients (mg/kg dry material) } \\
\hline N-source (A) & $\begin{array}{c}\mathrm{Zn} \text { rate } \\
(\mathrm{B}, \mathrm{kg} / \mathrm{fed})\end{array}$ & $\mathrm{N}$ & $\mathrm{P}$ & $\mathrm{N}$ & $\mathrm{Fe}$ & $\mathrm{Mn}$ & $\mathrm{Zn}$ & $\mathrm{Cu}$ \\
\hline \multirow{4}{*}{$\begin{array}{l}100 \% \text { RND } \\
\text { as a control }\end{array}$} & 0 & 19.05 & 4.01 & 28.63 & 49.82 & 21.10 & 16.85 & 8.80 \\
\hline & 1.0 & 20.96 & 5.51 & 31.54 & 55.67 & 26.71 & 34.50 & 10.00 \\
\hline & 1.5 & 23.25 & 6.84 & 35.08 & 59.40 & 30.45 & 39.47 & 12.10 \\
\hline & 2.0 & $25.07 *$ & $8.05 *$ & $39.36 *$ & $64.10^{*}$ & $34.90 *$ & $46.30 *$ & $15.02 *$ \\
\hline \multicolumn{2}{|c|}{ Mean } & 22.08 & 6.11 & 33.86 & 57.50 & 28.29 & 34.28 & 11.48 \\
\hline \multirow{4}{*}{$\begin{array}{l}75 \% \text { RND } \\
\text { without bio- } \\
\text { inoculation }\end{array}$} & 0 & 16.83 & 3.88 & 25.18 & 43.70 & 18.73 & 14.95 & 7.76 \\
\hline & 1.0 & 18.52 & 4.90 & 27.95 & 48.91 & 23.85 & 30.47 & 8.90 \\
\hline & 1.5 & 20.65 & 6.04 & 30.74 & 51.60 & 26.94 & 34.89 & 10.83 \\
\hline & 2.0 & 21.90 & 7.17 & 35.36 & 56.55 & 30.56 & 46.70 & 13.67 \\
\hline \multicolumn{2}{|c|}{ Mean } & 19.47 & 5.49 & 29.81 & 50.19 & 25.02 & 31.75 & 10.29 \\
\hline \multirow{4}{*}{$\begin{array}{c}75 \% \text { RND } \\
\text { with bio- } \\
\text { inoculation }\end{array}$} & 0 & 18.79 & 3.67 & 27.55 & 47.90 & 20.85 & 16.18 & 8.62 \\
\hline & 1.0 & 20.68 & 5.05 & 30.10 & 54.78 & 26.35 & 33.90 & 9.79 \\
\hline & 1.5 & 22.89 & 6.30 & 33.75 & 57.46 & 29.98 & 38.75 & 11.90 \\
\hline & 2.0 & $24.95 *$ & $7.90 *$ & $38.65 *$ & $62.95 *$ & $34.47 *$ & $45.67 *$ & $14.85^{*}$ \\
\hline \multicolumn{2}{|c|}{ Mean } & 21.78 & 5.72 & 32.56 & 55.72 & 27.91 & 33.62 & 11.29 \\
\hline \multirow{3}{*}{$\begin{array}{l}\text { L.S.D. at } \\
0.05\end{array}$} & $\mathrm{~A}$ & 0.57 & 1.02 & 3.03 & n.s. & 0.48 & 1.32 & 0.27 \\
\hline & B & 0.98 & 0.75 & 2.75 & 1.71 & 1.07 & 1.89 & 0.98 \\
\hline & $\mathrm{A} \times \mathrm{B}$ & 1.39 & n.s & 3.89 & n.s. & n.s. & n.s. & 1.65 \\
\hline \multicolumn{2}{|c|}{ *Relative decrease $\%$} & 0.48 & 1.86 & 1.85 & 1.79 & 1.23 & 1.36 & 1.13 \\
\hline
\end{tabular}

In this connection, these favourable conditions of nutrients uptake may be du to the increase in nitrogenase enzyme activity, which convert $\mathrm{N}_{2}$ into ammonia, however, Lata Saxena and Tilak, (2002) reported that supplying combined nitrogen by nitrogen fixing bacteria had affected the development and function of roots by improving mineral $\left(\mathrm{NO}_{3}{ }^{-}, \mathrm{PO}_{3}{ }^{-}\right.$and $\left.\mathrm{K}^{+}\right)$and water uptake. Also, Lifshitz et al. (1987) reported that bio-inoculation effect includes an increase in immobilization of insoluble nutrients followed by enhancement of uptake by the plants. These results are in line with those obtained by Massoud et al. (2004) who repotted that inoculation with $\mathrm{N}_{2}$-fixing bacterial increased uptake of $\mathrm{N}, \mathrm{P}, \mathrm{K}, \mathrm{Fe}, \mathrm{Zn}$, and $\mathrm{Mn}$ by plants.

Fayoum J. Agric. Res. \& Dev., Vol.24, No.2, July, 2010 


\section{REFERENCES:}

Abadi, Dawlat N.; M.H. Hegazy and Faiza K. Abd El-Fattah (1995). The interaction effect of inoculation and zinc application, growth and yield of soybean. Annals Agric. Sci., Ain Shams Univ., Cairo, 40 (1): 107-116.

Abdel-Ghaffar, A.S.; A.M. Hanna and F.I. Mohamed (1994). Factors affecting nitrogen fixation and yield of faba bean (Vicia faba) under Egyptian field conditions: A review .Arid Land Res. and Management, 1 (2): 65-75.

Abou-Zeid M.Y.; A.R. Al-Kasas and T.E.E. Radwan (2003). Wheat crop production and grain quality in response to nitrogen-fixing bacteria inoculation. Az. J. Pharm. Sci.,Vol. 31, December, pp. 79-73.

Aly, Mona M.M. (2003). Biological studies on some associative nitrogen fixing bacteria. M. Sc. Thesis, Fac. of Agric., Cairo Univ., Giza, Egypt.

A.O.A.C. (1980). Official Methods of Analysis. Association of Agriculture.

Ash. C.; F.G. Priest and M.D. Collins (1993). Molecular identification of RNA group 3 bacilli (Ash, Farrow, Wall Banks and Collins) using PCR probe test. Antonie Leeuwenhock, 64: 253-260.

Bhatia, A.; H. Pathak and H.C. Joshi (2001). Use of sewage as a source of plant nutrient: potentials and problems. Fert. News, 46 (3): 55-58.

Bakry, M.A.; A.M. Massoud and M.S. Awaad (2005). Effect of Azospirillum inoculation and fertilization with zinc and copper on wheat production and its components. Egypt J. of Appl. Sci., 20 (7): 333-348

Black, C.A.; D.D. Evans; L.E. Ensminger; J.L. White and F.E. Clark (1965). Methods of Soil Analysis. Am. Soc. of Agron. Inc., Madison, Wisconsin, USA.

Cakmak (2000). Possible roles of zinc in protecting plant cells from damage by reactive oxygen species. New Phyto., 146: 185-205.

Cottenie, A.; M. Verloo; L. Klekens; G. Velghe and Canielnc (1982). Chemical Analysis of Plant and Soil Laboratory. Analytical and Agrochemistry State Univ., Ghent-Belgium, $41 \mathrm{pp}$.

Difico Manual, (1984). Dehydrated Culture Media and Reagents for Microbiology. $10^{\text {th }}$ Edition. Difico Laboratories, Detroit, Michigan, USA.

El-Kabbany, E.A.Y. (1992): Biochemical studies on wheat as affected by some micronutrients. Ph. D. Thesis, Fac. of Agric., Menofiya Univ., Egypt.

Gouzou L.; G. Burtin; R. Philippy; F. Bartoli and T. Heulin. (1993). Effect of inoculation with Bacillus polymyxa on soil aggregation in the wheat rhizosphere. Preliminary Examination. Geogerma, 60.

Hardy, R.W.F.; R.C. Burns and R.D. Holsten (1973). Application of the acetylene-ethylene reduction assay for measurement of nitrogen fixation. Soil Biol. Biochem., 5: 47-81.

Hesse, P.R. (1971). A Text Book of Soil Chemical Analysis. John Murray (Puplish), London, UK.

Ibrahim, I.A.; A.S. Ahmed and W.E. Ahmed (1991). Effect of nitrogen source and zinc application methods on wheat. Zagazig J. Agric. Res., 18 (5): 1669-1674.

Jackson, M.L. (1967). Soil Chemical Analysis. Prentice-Hall, Inc. Limited, New York.

Fayoum J. Agric. Res. \& Dev., Vol.24, No.2, July, 2010 
Kloepper, J.W. (2003). A review of mechanisms for plant growth promotion by PGPR. $6^{\text {th }}$ international PGPR workshop. 65-10 October 2003, Calcutta, India.

Kloepper, J.W. and M.N. Schorth (1981). Plant growth promoting rhizobacteria and plant growth under genobiotic conditions. Phytopathology, 71: 642-644.

Kotb, M.Th.A. (1998). Response of wheat to bio-fertilizer and inorganic N and P levels. The Regional Symposium on agro-technologies Based on Biological Nitrogen Fixation for desert Agriculture. April 14-16, El-Arish, North Sinai Governorate. pp. 291-301.

Lata Saxena, A.K. and K.V. Tilak (2002). Bio-fertilizers to augment soil fertility and crop production. In: Soil Fertility and Crop Production. 9ed. Krishna, K. R.). Science Publishers, USA. pp. 279-312.

Lifshutz, R.; J.W. Kloepper and M. Kozolowski (1987). Growth promotion of canola (rapeseed) seedlings by a strain of Pseudomonas putida under genobiotics conditions. Can. J. Microbial, 33:390-395.

Mahmoud, M.M. (2001). Studies on some factors affecting the implication of applying zinc and copper to the soil-plant system. Ph. D. Thesis, Fac. of Agric. at Moshtohor, Zagazig Univ., Egypt.

Markus, D.K.; J.P. Mckinnon and A.F. Buccafuri (1982). Automated analysis of nitrate and ammonium nitrogen in soils. New Jersey Agric. Exp. Sta. Publication No. D. 15117-84. Supported by state funds presented in part before Div. S-4 Soil Soc. of Am. Anaheim, CA.

Massoud A.M.; M.Y. Abou-Zeid; El-Sayeda A. Hassan and S.F. El-Fiki (2008). Influence of phosphate dissolving and nitrogen fixing bacteria on faba bean under different levels of phosphorus fertilization. J. Agric. Sci. Mansoura Univ., 33 (11): 7991-8007.

Massoud, A.M.; H.M. Salem; I.M. Farid and M.A. Nasef (2004). Response of pea plants grown on a clay soil to Rhizobium Inoculation combined with Mo and $\mathrm{Zn}$ as foliar application. Annals of Agric. Sc., Moshtohor, 42 (3): 1431-1440.

Mavingue, P.; O. Berge and T. Heulin (1990). Immunotrapping of Bacillus polymyxa in soil and in the rhizosphere of wheat. Symbiosis. 9; 215-221.

Moharram, T.M.M.; M.S.A. Safwat; M.M. Farghaly and M.Z. Ali, (1997). Effect of inoculation with Bacillus polymyxa on growth and nitrogen fixation of wheat under graded levels of inorganic and organic nitrogen. Egypt J. of Microbial, 32 (1): 1-15.

Mohsen, K.,; H. ebrahim and M.A. Magda (2004). Physiological response to foliar application of zinc and inoculation with some bacterial fertilization. J. of Plant Nutrition, 27 (10): 1859-1874.

Moore, P.A. and W.H. Patrick (1989). Effect of zinc deficiency on alcohol hydrogenase activity and nutrients uptake in rice. Agron. J., 80:882-885.

Moursy, M.E.; M.Y. Abou-Zeid and A. Wahba (2008). Response of Soybean to phosphorus fertilizer under the effect of some plant growth promoting rhizobacteria. J. Agric. Sci. Mansoura Univ., 33 (10): 7473-7473.

Palm, C.A.; C.N. Gachengo; R.J. Delve; G. Cadisch and K.E. Giller (2001). Organic inputs for soil fertility management in tropical agro

Fayoum J. Agric. Res. \& Dev., Vol.24, No.2, July, 2010 
BIO-INOCULATION AND Zn APPLICATION AS AN ALTERNATIVE... 116 ecosystems: application of an organic resource database. Agric. Ecosyst. Environ., 83 (1-2): 27-42.

Peterburgski, A.V. (1968). Hand Book of Agronomic Chemistry. Kolas Publishing House, Moscow (In Russian pp. 29-86) (c.f. Shamas El-Din, H.A., 1993, Ph.D. Thesis, Mansoura Univ.).

Ramadan, Heba E.; M.A. Ali; Heba Shehata; M. El-Kattan and M. Fayez. (2007). Diazotroph-bioagent-Pathogen panorama towards the production of environmentally safe cucumber. J. Agric. Sci. Mansoura Univ., 32 (5): 3963-3709.

Reda M.M.A.; Faten M. Mohamed; S.F. Mansour and M.Y. Abou-Zeid (2006). Interaction between sugar lime, sulphur and applied bio-inorganic $\mathrm{N}$ fertilization on saline sodic soil properties and wheat production. Egypt J. of Appl. Sci., 21 (6A): 353-372.

Romheld, V. and H. Marshschner (1991). Function of micronutrients in plants. In: Micronutrients In Agriculture. Published by Soil Sci. Soc. Amer., Inc. Madison, Wisconsin, USA. 297-299 pp.

Singh, N.P.; R.S. Sachan.; P.C. Pandey and P.S. Bisht (1999). Effect of a decade long fertilizer and manure application on soil fertility and productivity of rice-wheat system in Molisols. J. The Indian Soc. Soil Sci., 47 (1): 72.-80.

Snedecore, G. W. and W. G. Cochran (1980). Statistical methods. $7^{\text {th }}$ Ed., Iowa State Univ., Press, Amer., Iowa, U.S.A.

Vallee, B.L. and K.H. Falchuk (1993). The biochemical basis of zinc physiology. Physiol. Rev., 73: 79-118.

Vessey, J.K. (2004). Benefits of inoculating legume crops with rhizobia in the northern Great Plains. Online. Crop Management, doi:10.1094/CM-20040301-04-RV.

Wettstein, D. (1957). Chlorophyll-lethale und der submikroscopische formwechsel der plastiden. Exptl. Cell. Res., 12: 427-433.

Yamaguchi, M. and A.P. Minges (1956). Brown checking of celery, assumption of boron deficiency. I: Field observations. Variety Susceptibility and Chemical Analysis. 
التلقيح الحيوى وإضافة الزنك كبديل إستيراتيجى لإحلال جزئى من إحتياجات النتروجين المعدنى

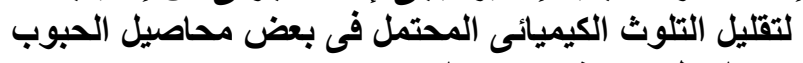

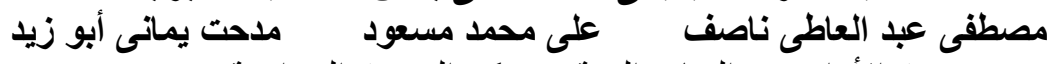

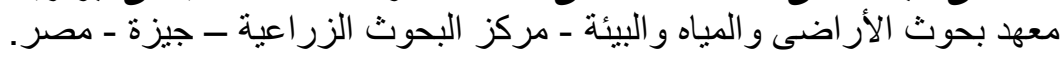

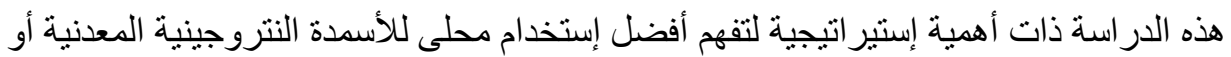

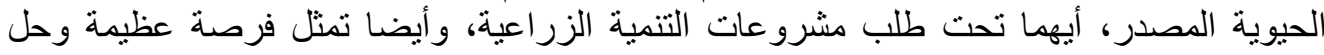

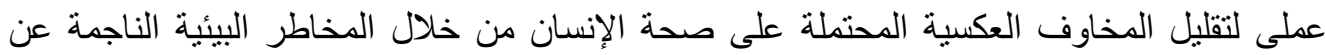

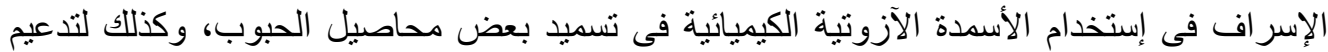

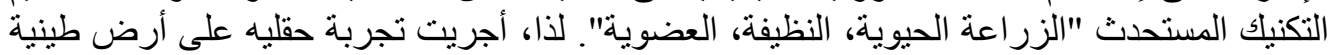

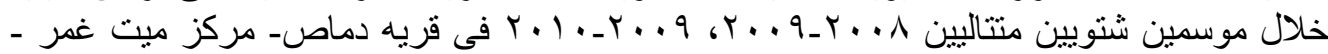

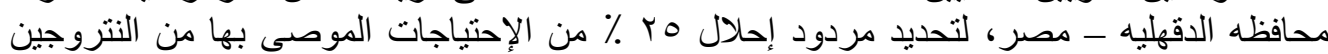

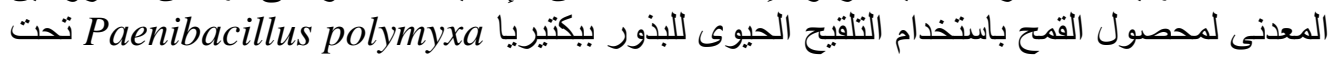

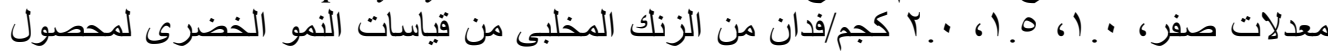

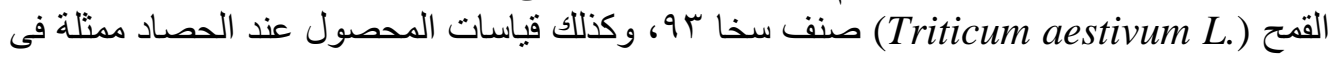

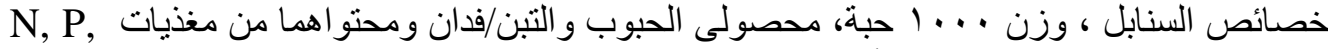
K, Fe, Mn, Zn and Cu الميسر فى صورتيه (

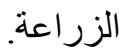

وتثير النتائج إلى أن التلقيح الحيوى للحبوب وإضافة الزنك المخلبى كما هو في المعاملة

(Paenibacillus polymyxa bacteria + 75 \% RND + highest Zn rate of $2 \mathrm{~kg} / \mathrm{fed}$ )

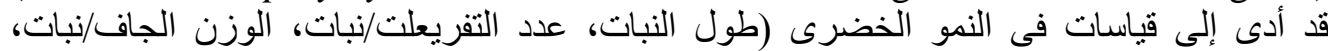

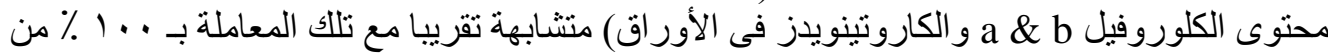

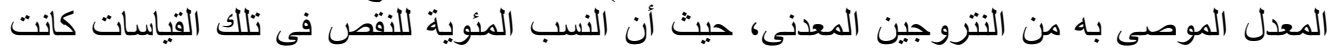

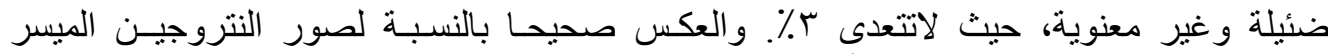

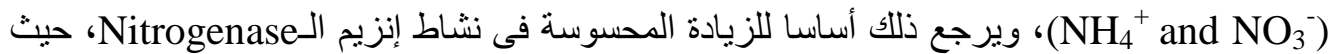

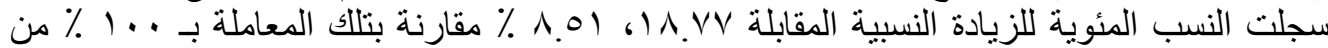

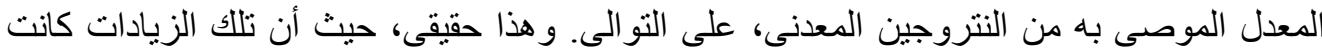

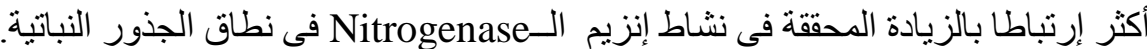

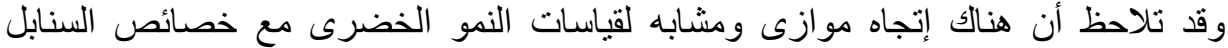

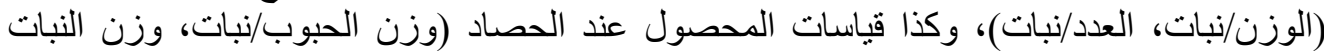

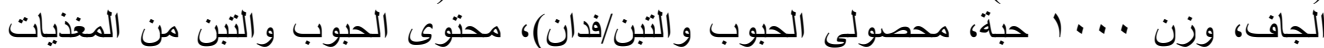

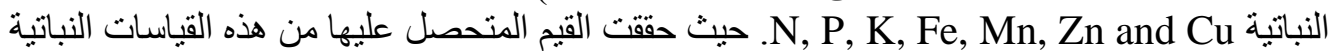

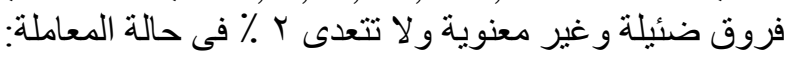
(Paenibacillus polymyxa bacteria + 75 \% RND highest Zn rate of $2 \mathrm{~kg} / \mathrm{fed}$ )

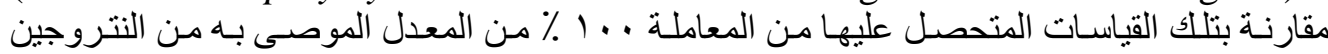

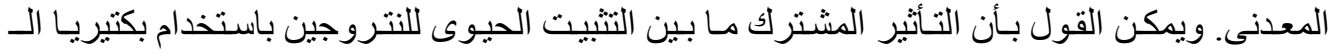
Paenibacillus polymyxa

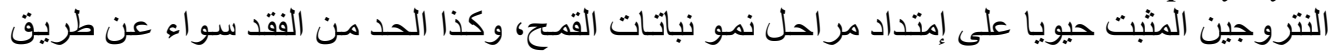

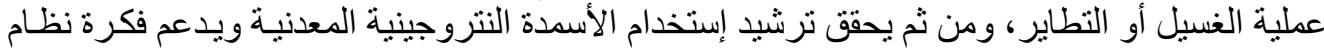

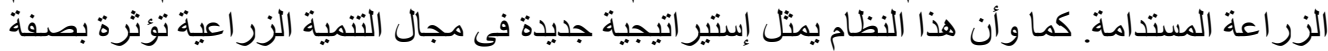

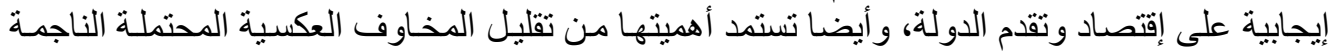

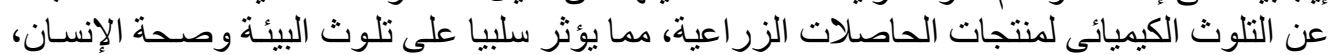

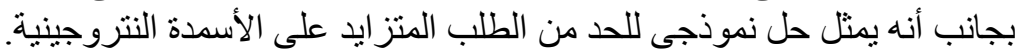

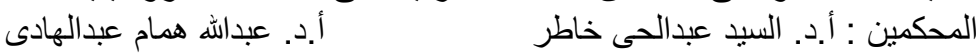

Fayoum J. Agric. Res. \& Dev., Vol.24, No.2, July, 2010 